\title{
THE CONCEPT OF PLEA BARGAINING UNDER THE CZECH CRIMINAL LAW AND THE CRIMINAL LAW OF OTHER COUNTRIES WITHIN THE REGION OF CENTRAL EUROPE
}

\author{
Filip Ščerba ${ }^{1}$
}

\section{Faculty of Law, Palacký University Olomouc, Czech Republic email: ondrej.svacek@upol.cz}

ŠČERBA, Filip. The Concept of Plea Bargaining under the Czech Criminal Law and the Criminal Law of other Countries within the Region of Central Europe. International and Comparative Law Review, 2013, Vol. 13., No. 1, pp. 7-22. DOI: 10.1515/iclr-2016-0055.

\begin{abstract}
The article deals with the specific instrument used in criminal proceedings called as plea bargaining, or agreement upon the guilt and punishment (in the Czech legal regulation). This instrument is considered as one of the main measures used for acceleration of criminal proceedings and for criminal justice rationalization. Plea bargaining originally belongs to the system of criminal law in the countries belonging to the Anglo-Saxon legal order, but it has been implemented also into the legal orders of countries in Middle Europe region during last decade. Such implementation in connected with some important problems related to the different characteristics of criminal proceedings. The article solves some of these problems, primarily the collision with the basic principles of continental system of criminal law.
\end{abstract}

Keywords: criminal law, criminal proceedings, plea bargaining, Czech Republic, Central Europe.

\section{Criminal Justice Rationalization}

Performing of the acts within criminal proceedings usually takes too long and thus this phenomenon can be regarded as one of the most burning problems which have plagued the criminal justice not only in the Czech Republic but at least all over Europe for the last few decades. This phenomenon, among other things, obviously results from considerable extension of criminal law under which a whole range of illegal acts is settled through criminal sentencing. These acts previously fell within the area of different legal fields. In addition to this, new social phenomena (in economic field as well as phenomena occurring as a result of intensive development of communication technologies, etc.) have also necessitated protection by means of criminal law norms. The significance of this issue

1 Filip Sčerba is a Senior Lecturer at Department of Criminal law, Faculty of Law, Palacký University in Olomouc, Czech Republic. Email: filip.scerba@upol.cz. 
is closely connected with the fact that unreasonable delays in criminal proceedings represent violation of the right to hearing of the case within a reasonable period of time resulting from the European Convention upon the protection of human rights and fundamental freedoms (compare article 6 clause 1 of the Convention).

This problem obviously has to be dealt with and thus the need to tackle this issue has resulted in the trend which is sometimes called Criminal Justice Rationalization. It means that the state strives to introduce and enforce methods supporting the increase in efficiency of the criminal justice in order to make the criminal proceedings shorter and administrative procedure easier.

The initial stage of the rationalization process was logically focused on dealing with less serious criminal offences which have made the criminal justice system more and more overloaded; offences committed in connection with road traffic could be a typical example with a sharp increase in the volume of car traffic logically bringing about an increase in crimes committed in this area. Both legal study as well as the legislator have come to the conclusion that it is not necessary to carry out all the acts within the criminal proceedings which can often be lengthy and expensive. It is especially possible to solve the case through an out of court settlement and thus refrain from hearing the case before the court. If the prosecuted person agrees with this then the case can be settled before trial hearing before the court. However, this can only be done with the consent given by the person prosecuted. ${ }^{2}$

This resulted in the introduction of institutes such as e.g. criminal order or so-called diversions of criminal proceedings. The application authorities were keen to accept the newly introduced tools (or at least some of them) as a way to simplify their work as they (e.g. diversions of criminal proceedings) represent certain advantages not only for the criminal justice system but also for the victim of a crime. ${ }^{3}$

As far as the Czech Republic is concerned the first stage of the rationalization process dates back to the 90 's of the $20^{\text {th }}$ century and the first decade of the $21^{\text {st }}$ century when several amendments into the Czech Criminal Procedure Code were made (Act N. 141/1961 Coll.) In 1993 the possibility to handle a case through criminal order was re-established through the Amendment N. 292/1993 Coll. valid from January 1, 1994. Under this law a case can be handled through criminal order if it is the single judge who is competent to hear and try such a case (this way of trying cases had been abolished through the Amendment $\mathrm{N}$.

2 In this respect it can be said that this phenomenon to a certain extent challenges the right of general conception of a crime, which is based upon the notion that a criminal act is punishable by the court.

3 Compare e.g. Adler, F., Mueller, G. O. W., Laufer, W. S.: Criminology. McGraw-Hill, New York 1991, s. 356-357; Nezkusil, J.: Odklon v trestním řízení. Karlovarská právní revue 2005, č. 2, s. 37-39; Rozum, J., Kotulan, P., Vůjtěch, J. Výzkum institutu narovnání. IKSP, Prague 1999, p. 9. 
178/1990 Coll.). Through the same amendment the first type of diversion was also enshrined in the Czech Criminal Law - a diversion which is called conditional discontinuance of criminal proceedings. Two years later the first type was followed by the second one (as a result of the adoption of the Criminal Procedure Code Amendment N. 152/1995 Coll.) This type of diversion is called settlement. Within the following ten years other two types of diversion were introduced, namely it was conditional discontinuance of filing a motion to punishment and abandonment of criminal prosecution in proceedings against juvenile offenders.

Elements making the criminal proceedings run faster could also be seen in the so-called great amendment of the criminal procedure code carried out through the Act N. 265/2001 Coll. (valid from January $1^{\text {st }}, 2002$ ). This amendment modified the legal regulation of appellate proceedings in favor of the appellate principle with the aim to make the proceedings before the court run faster. However, it was possible to solve less serious cases in a simpler and faster way due to the introduction of the possibility to carry out shortened pre-trial proceedings ( $\$ 179 \mathrm{a}$ and subsequently of the criminal procedure code) and subsequent summary proceedings before the court.

If the first stage of the rationalization process is to be characterized as one focused on dealing with less serious crimes, then it is possible to define the year 2012 as the breakthrough in the system of the Czech criminal law as the Czech legislator - following some other states' example - agreed to the introduction of an institute, the aim of which is also to accelerate criminal proceedings which, however, at the same time does not only apply in cases of less serious crimes. This institute is called the agreement upon the guilt and punishment, which was originally mentioned in connection with the system of criminal law in the countries belonging to the Anglo-Saxon legal order where it is frequently called plea bargaining. This step was not unexpected at all as there had already been two unsuccessful proposals of similar nature submitted for approval to the Chamber of Deputies of the Czech Republic. The introduction of this institute is also touched upon in the intended subject matter of the re-codification of the criminal procedure code.

\section{Plea Bargaining and the Continental legal system}

Making an agreement between the accused (who is represented by an advocate) and the prosecution (represented in the Czech Republic by the state attorney) can be regarded as the fundamental principle behind the institute of the agreement upon the guilt and punishment. This agreement includes the defendant's confession to the crime committed and accurate definition of legal consequences drawn as a result of the commission of this crime. These consequences

4 In the following text the expression agreement upon the guilt and punishment will be used in connection with the Czech and Slovak legal regulation as a literal translation of the term used in the Czech and Slovak legal norms. 
especially in the form of a concrete punishment are drawn by the state as a reaction to the crime committed. If this agreement is supposed to have the power and effect of a conviction it must subsequently be approved by the court.

The advantages resulting from the employment of this institute can be easily seen in considerable acceleration of criminal proceedings contributing to the fulfillment of the international and constitutional requirements mentioned above. It also contributes to the simplification of the process of giving evidence, easies the performance of the bodies responsible for criminal proceedings and last but not least solving of cases through the agreement upon the guilt and punishment can also be beneficial from the viewpoint of the efficiency of criminal law bearing in mind that the reaction of the criminal law to the crime committed is all the more effective if it follows immediately after the crime was committed.

On the other hand the institute of plea bargaining under the system of continental criminal law represents a foreign element as it collides with certain fundamental principles upon which the criminal proceedings (falling within the continental legal system) is based. It specifically collides with the principle of legality and the principle of material truth. After all this point is frequently raised by many of those who strongly oppose the idea of the introduction of the institute of the agreement upon the guilt and punishment. ${ }^{5}$

The extraneousness of the institute of plea bargaining from the viewpoint of continental system of criminal law results from a different concept of the role of the judge in criminal proceeding. The system of Anglo-Saxon criminal law is based on adversarial model of criminal proceeding in which the prosecutor has a very strong position and a large discretionary power, whereas the judge plays the role of a passive arbitrator with limited powers. By way of contrast the continental system of criminal law is based on inquisitorial court procedure where the roles of the parties mentioned above are to a certain extent reversed, i.e. the court plays much more active role in the criminal proceedings and in the last instance it is responsible for the proper clarifying of the facts of a case. ${ }^{6}$

The number of those countries whose legal order is based on the continental system of law and still adopt the element of plea bargaining as a part of their legal regulation is on the increase. However, the legislators in these jurisdictions are trying to enshrine this institute in their legal systems so that their traditional system of their jurisdictions would not be upset if possible, i.e. they try to minimize

5 Within the Czech professional literature comp. especially Musil, J.: Dohody o vině a trestu jako forma konsenzuálního trestního rrízení. Kriminalistika 2008, no. 1, p.. 3-26; Musil, J.: Dohody o vině a trestu - ani či ne? In: Rekodifikácia trestného práva - doterajšie poznatky a skúsenosti. Zborník príspevkov z celoštátneho seminára s medzinárodnou účastou konaného dňa 21. apríla 2008. Bratislava: The school of law in Bratislava, 2008, p. 179-201; Novotný O.: Je naše trestní právo procesní v krizi? Trestní právo 2006, no.. 7-8, p. 28-31.; Protivinský, M., Kratochvíl, V.: Jsou dohody v trestním ř́zení prípustné a nutné? Kriminalistika 2004, no. 3, p. 239-242.

6 Compare e.g. Turner, Jenia I.: Plea bargaining across borders. Aspen, 2009, p. 76-77. 
the intervention into the principles of court procedure applied in the criminal proceedings of the continental legal systems. Thus we can see the rise of a new type of the institute of plea bargaining which in certain features differs from its original model applied in the Anglo-Saxon jurisdictions.

This phenomenon can be clearly seen within the region of Central European jurisdictions and has become frequent in these systems of criminal law in the last decade, which can be demonstrated not only by the new legal regulation valid in the Czech Republic, but also by the legal regulations of Germany or Slovakia respectively. As far as the German legal regulation is concerned, the institute of plea bargaining was implemented into this legal regulation in an unusual way. First agreements (Absprachen) between the prosecution and the defense were made and respected and followed by the courts in practice and it was only later in 2009 when the legal regulation was changed. ${ }^{7}$ Thus it was explicitly stated that these steps in the criminal proceedings can be taken and the institute was regulated in a greater detail. As far as the Slovak system of criminal law is concerned the institute of the agreement upon guilt and punishment was adopted as a result of the re-codification of the system of criminal law, which was carried out in 2005 and also resulted in the adoption of a new criminal law statute (Act N. 300/2005 Coll., criminal law) and it also resulted in the adoption of criminal procedure code (Act N. 301/2005 Coll., Criminal Procedure Code); both regulations have been valid form January $1^{\text {st }}, 2006 .^{8}$

\section{Plea Bargaining and the Principle of Material Truth}

As it has been outlined above the existence and implementation of the institute of plea bargaining in the continental law jurisdictions collides with certain fundamental principles upon which the criminal proceeding in these jurisdictions is based. This can be regarded as the main problem. This obviously relates to the systems of Czech, Slovak as well as German criminal law.

The first principle which has to be mentioned in connection with the institute of plea bargaining is the principle of material truth. This principle states that the bodies in criminal proceedings must clarify the facts of the case beyond reasonable doubt to such extent that a decision can be made; the defendant's confession does not mean that these bodies are freed from the duty to review all the circumstances and facts of the case. This can be regarded as one of the characteristic features of the principle of material truth (compare $\$ 2$ clause 5 of the Criminal

7 See more in Musil, J.: Dohody o vině a trestu (Absprachen) v Německu. Právník 2008, no. 3, p. 217-246.

8 Here it is good to note that tle Slovak legal regulation deals with the institute of the agreement upon the guilt and punishment as with one of the diversions in the criminal proceedings (compare e.g. Klátik, J.: Zrýchlenie a zhospodárnenie trestného konania. Banská Bystrica: Matej Bel University, 2010, p. 127 and subsequently; Ivor, J. a kol.: Trestné právo procesné. Bratislava: IURA EDITION, 2006, p. 59), even when this type of settling a case is not connected with termination of criminal proceedings. 
Procedure Code, $\$ 2$ clause 10 of the Slovak Criminal Procedure Code, $₫ 244$ clause 2 of the German Criminal Procedure Code).

The potential collision between the principle of material truth and the institute of plea bargaining is obvious - this institute is directly aimed so that the process of evidence presenting could be completed in a significantly limited scope, which should consequently result in shortening of the criminal proceeding. ${ }^{9}$ After all this element can also be found to a certain extent in other institutes, the aim of which is to rationalize the criminal proceeding, no matter whether this is the diversion in criminal proceeding or a special type of decision in the form of criminal order. In comparison with the diversions in criminal proceeding the institute of plea bargaining is not reserved merely for dealing with petty cases. In such cases there is no need to carry out the whole proceedings nor is it necessary to deliver a judgment in the form of a sentence. ${ }^{10}$ As far as the application of criminal order is concerned it is explicitly in the competency of the court, whereas the institute of plea bargaining is primarily based upon the agreement between the main parties to the criminal proceedings, i.e. it can be said that the material truth has been agreed upon.

It can be said that the Czech legislator obviously tried to frame the new legal regulation of the institute of the agreement upon the guilt and punishment in such a way that it would not collide with the principle of material truth if possible. The commencement of the agreement upon the guilt and punishment is, under the Czech Criminal Procedure Code, conditioned by the fact that the investigation results sufficiently prove that the act has been committed, the act is a crime and that the defendant did commit the crime (compare $\$ 175$ a clause 1 of the Criminal Procedure Code). This procedure is conditioned by the investigation results no matter whether the state attorney is supposed to act out of his own initiative or react to the impulse given by the defendant. However, the requirement stipulated in the provision $₫ 175$ a clause 3 is even more important. Under this provision the state attorney is allowed to make an agreement with the defendant upon the guilt and punishment only in cases when the preliminary proceedings results do not challenge the verity of the defendant's statement about the commission of the crime prosecuted.

Thus the state attorney, as an authority responsible for the proper performance of the preliminary proceeding, is responsible for the following of the principle of material truth even in those cases when the preliminary proceeding is supposed to result in an agreement upon guilt and punishment. As a matter of fact it can be said that the state attorney should agree to the solution of the case through the agreement upon the guilt and punishment only in cases when the

9 Compare Newman, D. J., Anderson, P. R.: Introduction to Criminal Justice. Fourth edition. Random House, New York 1989, p. 632.

10 As to the characteristic features of diversions in criminal proceedings see Ščerba, F.: Alternativni tresty a opatření v nové právni úpravě. Prague: Leges 2011, p. 52-57. 
investigation results objectively prove the legitimacy of the prosecution in such a quality which is sufficient for filing an action in standard cases. After all submitting of the agreed agreement upon the guilt and punishment for approval by the court is just another way of bringing the defendant before court.

Also the court has to take into account the material truth when in the process of assessing and approving of the agreement upon the guilt and punishment submitted by the state attorney. This results from the provision $\$ 314 \mathrm{r}$ clause 2 of the criminal procedure code, under which the court shall not accept the motion to the agreement upon the guilt and punishment also in such cases when the agreement submitted is not consistent with the ascertained facts of the case. This rule can be interpreted in such a way that even insufficiently ascertained (i.e. not completely ascertained) facts of the case can serve as a reason for not approving of the submitted agreement upon the guilt and punishment by the court. Opposing interpretation would thus mean that the court - as far as the scope of the necessary evidence provided is concerned - is bound by the opinion of the state attorney, which would in fact deny the rule enshrined in the Constitution (article 90 of the Constitution, article 40 clause 1 of the Fundamental Charter), under which it is the court which shall decide upon the guilt and punishment.

Under the new Czech legal regulation both the state attorney as well as the court are under the obligation to find out the facts of the case so that the content of the agreement upon the guilt and punishment made between the prosecutor and the defendant is in harmony with the objective facts, thus they have to thoroughly review the defendant's confession. Thus the Czech legal regulation does not represent a real breakthrough in the principle of material truth but rather its modification.

The Slovak legal regulation, which definitely served as an inspiration to a certain extent for the Czech legislator as far as the institute of agreement upon the guilt and punishment is concerned, is based upon similar principles and also takes into account the principle of material truth significantly. Even under the Slovak criminal procedure code mere confession of the defendant is not enough to commence the proceedings based on the agreement upon the guilt and punishment, but the prosecutor (i.e. the person representing the prosecution) can commence the proceedings only in such cases when at the same time the investigation results (or the results of the summary proceedings) sufficiently justify the conclusion that the act committed is a crime and that the defendant did it and the evidence is in accordance with the confession made by the defendant $(\$ 232$ clause 1 of the Slovak criminal procedure code).

However, there are some differences between the Slovak and Czech legal regulations as far as the conditions for denying (or not approving) the motion for agreement upon the guilt and punishment is concerned. Under the Slovak legal regulation the court (or the senate chairman) can refuse to accept the motion for 
agreement upon the guilt and punishment if it is obviously unreasonable [compare $\$ 331$ clause 1 letter $b$ ) and the clause 2 of the Slovak criminal procedure code]. Thus the court can refuse to accept the agreement if it is considered to be unfair (compare $\$ 334$ clause 2 and 3 of the Slovak criminal procedure code).

As far as the German criminal law is concerned it takes into account the principle of material truth significantly when negotiating about the punishment between the parties to criminal proceedings. This is closely connected with the fact that under the German criminal procedure code (as compared with the Czech and Slovak legal regulation) the institute of plea bargaining is not designed as a special and separate mode of proceedings, but as a specific right of the court to make an agreement with the two parties during the trial (compare $\$ 257 \mathrm{c}$ of the German criminal procedure code). Thus the obligation to prove all the relevant factual circumstances of the case which results from the principle of material truth ( $\$ 244$ clause 2 of the German criminal procedure code) must be complied with.

The previously announced taking into consideration of the material truth can also be seen in the provision $\$ 257$ c clause 5 of the German criminal procedure code under which the court is not bound any more by the agreement to settle a case made with the defendant and the prosecutor if within this agreement legal or other important factual circumstances were not taken into consideration or if such new circumstances emerged if the court at the same time arrives at a conclusion that the expected terms of punishment do not fit the gravity of the crime or the level of guilt any more. ${ }^{11}$ This means that objective and correct finding of the facts of the case (i.e. material truth) along with legal assessment of the case must have priority even in such cases when all three main legal parties (defendant, state attorney and the court) have explicitly agreed to the agreement.

However, at this stage it must be emphasized that the conditions and interpretation of the legal regulation of the institute of plea bargaining outlined above from the viewpoint of the principle of material truth does not necessarily mean that the state attorneys and judges will respect and apply this institute in practice. After all opinions frequently appear in professional literature according to which the idea of a thorough review of the confession made by the accused is nothing more than just a "pious hope of the legislator". 12

However, the fact that the principle of material truth must be respected even in the proceeding involving the agreement upon the guilt and punishment resulting from the legal regulation brings another consequence, i.e. the Central

11 The same holds in cases when the defendant's behavior in the subsequent proceedings (after the agreement has been made) does not correspond with the circumstances the court took into account when making the agreement. Thus the defendant's confession in such cases cannot be used in the subsequent proceedings.

12 Musil, J.: Dohody o vině a trestu jako forma konsenzuálního trestního řízení. Kriminalistika 2008, no. 1, p. 15. 
European concept of the institute of the plea bargaining is different from the Anglo-American one. If the material truth is still supposed to have priority over the formal (agreed) truth it is not possible to legally qualify the act committed as a part of the negotiation between the state attorney and the defendant.

In the Anglo-Saxon legal jurisdictions negotiating about the legal qualification of the act committed is quite common. ${ }^{13}$ However, the situation in Central European Region is different, i.e. if the equal position of both parties is to be kept it is not admissible for the same acts to be assessed in different ways merely for the purpose of making the criminal proceedings run faster. In other words under the Central European continental criminal law system it is not possible for the state attorney or the court to derive knowingly a wrong legal assessment of the act committed on the basis of the facts of the case. ${ }^{14}$ In this respect the German legal regulation can be used to demonstrate this problem, namely the provision $\S 257$ c clause 2 of the German criminal procedure code, which explicitly rules out the possibility to make an agreement between the two parties in such a way that it would include the statement of guilt (and thus the legal assessment of the act committed).

\section{Plea Bargaining and Securing the Right to a Defense}

The principle of material truth and its application in the conference procedure adjusting the initial views and opinions is closely connected with other principles of criminal proceedings, i.e. the principle to secure the right to a defense [compare especially article 6 clause 3 letter b) of the European Convention on the human rights protection and the protection of fundamental freedoms]. The legislators within the region of Central Europe are fully aware of this, emphasizing the importance of the right to a defense saying that violation of this right is one of the main reasons why the courts cannot accept the motion for agreement upon the guilt and punishment [compare $\$ 314 \mathrm{r}$ clause 2 of the criminal procedure code, $\$ 331$ clause 1 letter $b$ ) of the Slovak criminal procedure code]. Securing of the right to a defense within the process of plea bargaining is especially connected with the fact that this type of settlement of the case can potentially threaten not only the public interest to properly and fairly sanction the offender who has committed a crime, but it is also connected with the risk posed in such cases when the offender knowingly and intentionally makes a wrong confession, which has been made by the offender for the purpose of getting less severe punishment even if the offender should be wrongly convicted.

Again it is possible to point out that the same problem has been for a long time connected with the application of diversions in the criminal proceedings

13 Compare e.g. Štěpán, J.: Některé rysy trestního řízení ve Spojených státech. Právo a zákonnost 1991, no. 5, p. 298-299.

14 The same in Král, V.: Dohoda o vině a trestu v návrhu novelizace trestního řádu. Právní rozhledy 2008 , no. 20 , p. II. 
(as the application of these diversions is conditioned not only by the confession made by the defendant, but also by the consent of the defendant to such a settlement of the case), but also with the use of criminal order (when such an order has been issued the accused can hesitate whether to accept the punishment imposed by the order or file a protest even when the filing of such a protest is not connected with the prohibition of reformation in peius, which means that even harder punishment could be imposed). This problem becomes all the more serious in connection with the institute of plea bargaining as the application of diversions or the use of criminal orders cannot lead to such hard sanctions as it would be in case of the agreement upon the guilt and punishment within the institute of plea bargaining. ${ }^{15}$

There is a question to what extent or if it is important at all to take into account the risk of a false confession. This is obviously connected with the scope of paternalism used by the state towards the defendant in the criminal proceedings. The system of continental criminal law has traditionally been much more caring in this respect as compared to the Anglo-Saxon system of criminal law. Thus it is not surprising that in the Central European system of law the legislator has tried to set the conditions for the use of the institute of plea bargaining so that even in these cases the risk of unfair conviction based on false confession of the accused would be minimized.

Thus the basic guarantee is, in this respect, the requirement (outlined above) to objectively find out the facts of the case verified by the confession made by the defendant - i.e. following the principle of material truth analyzed above. However, as it has been said, the fact that this requirement is covered by the legal regulation does not necessarily mean that it will be properly followed by the authorities in the criminal proceedings. In this respect it is rightful to analyze other possibilities of guarantees which could help to eliminate the risks of false confession made knowingly by the accused or generally speaking to strengthen the right of the accused to defense.

The institute of a compulsory defense (i.e. a compulsory representation of the accused by the counsel for defense) can be regarded as one of these types of guarantees. This type of defense could serve as one of the presuppositions for settling a criminal case through plea bargaining. As far as Central European legal regulations and the views upon the utility of the institute of compulsory defense in this special type of criminal proceeding are concerned there are different views upon these issues. Under the Slovak criminal law the agreement upon

15 When applying the diversion the formal conviction of the defendant is not realized, and the criminal order cannot be used to impose e.g. unsuspended prison sentence, which is true when talking about the Czech criminal law (compare $\$ 314$ e clause 2 of the criminal procedure code), and also the German criminal law (compare $\$ 407$ clause 2 of the German criminal procedure code); under the Slovak criminal procedure code it is possible to impose the imprisonment sentence, even up to the period of three years (compare $\$ 353$ clause 2 of the Slovak criminal procedure code). 
the guilt and punishment is not seen as a good reason for the use of compulsory defense institute, however, under the Czech criminal procedure code (provision $\$ 36$ clause 1 letter $d$ ) of the criminal code, it is said that the accused must have a defender when negotiating the conditions of the agreement upon the guilt and punishment.

Thus the Czech legislator took a careful approach towards the rights of the accused in the proceedings dealing with the agreement upon the guilt and punishment trying to secure an equal position of both the defense and the state attorney when negotiating the conditions in the agreement upon the guilt and punishment. By the way this is the reason why, under the Czech criminal procedure code, the compulsory defense is connected merely with the process of negotiating the conditions of the agreement upon the guilt and punishment itself. After the agreement has been made the accused does not have to be represented by the defender, not even at the stage when the court is in the process of decision-making about the approval of the agreement. It is just during the process of making the agreement with the state attorney when the accused significantly weakens his procedural position by his confession to the act prosecuted. Professional legal assistance provided by the counsel for defense also helps to prevent the state attorney from using undue duress upon the accused. ${ }^{16}$ Last but not least it is important to point out that the state attorney (sometimes also called the person representing the prosecution) is a professional whose knowledge and experience can play a bigger role in the process of negotiating about the guilt and punishment of the accused as compared to the trial where this drawback on the part of the accused can be balanced to at least certain extent by the impartial judge who is fully in charge of this stage of criminal proceedings.

\section{Plea Bargaining and the Principle of Adequacy of Punishment}

Up to now the (in)consistency of the institute of plea bargaining with certain principles governing criminal proceedings has been analyzed, however, now it is important to deal with a collision of this institute colliding with a substantive law principle which belongs to the fundamental principles of sentencing - the principle of adequacy of punishment ( $\$ 38$ of criminal code, $\$ 34$ clause 4 of the Slovak criminal code, $\$ 46$ of German criminal code).

Criteria which must be followed by the court when setting the terms of punishment (the gravity of the act committed, the person and circumstances of the perpetrator, the possibilities of correction of the offender etc.) are purely substantive law criteria. The procedural way of settling a case should have no impact on setting the terms of punishment. Logically the same act and the same perpetrator should result in the same punishment, regardless of the procedural method through which the perpetrator was convicted.

16 Hrušáková, M., Jiříček, P.: Dohoda o vině a trestu z pohledu obhajoby. In: Ščerba, F. a kol: Dohoda o vině a trestu a další prostředky racionalizace trestní justice. Prague: Leges 2012, p. 35. 
Here it is important to point out that in practice (at least the practice of Czech authorities in criminal proceedings) the procedural way of settling a case has a significant effect on the punishment of the offender. For example the statistical data ${ }^{17}$ reliably speak about the fact that since 2002, when the amendment came into effect, making it impossible to impose through a criminal order an imprisonment sentence, the number of cases settled in this way has lowered and the number of those cases settled through imposing the community service punishment has adequately increased. It was because judges sitting alone often preferred a faster settling of a criminal case (through the issuing of a criminal order) to lengthy and more difficult performance of trial even though instead of imposing an imprisonment sentence, originally imposed in such cases they now imposed they were forced to apply 'only' (at that time)the second most severe punishment, i.e. the community service. ${ }^{18} \mathrm{~A}$ similar phenomenon can be expected in cases when the judges apply the institute of the agreement upon the guilt and punishment. The courts will thus be willing to impose less severe sanctions, compared to those they would have chosen when imposing sanctions through delivering a judgment if this in turn results in making the criminal proceedings faster and lowering the number of pending cases.

It is necessary to say that this is, in fact, the basic principle behind the agreement upon the guilt and punishment from the viewpoint of the accused, i.e. receiving of a less severe sanction as a kind of reward for the confession made, bearing in mind that the accused is primarily motivated to make this agreement by the possibility to bargain a less severe punishment compared to the form of punishment he would probably get if the case was settled through a standard conviction. ${ }^{19}$ However, in spite of this fact, this phenomenon (i.e. less severe punishment of the offender compared to the one the offender would have received in case of standard procedure) represents a very problematic aspect of the institute of plea bargaining. The objection connected with this issue which is quite justifiable cannot be ignored, i.e. if the aim of the criminal proceeding is to realize material criminal law, the procedural criminal legal regulation should not try to appropriate the legitimacy to set a special criterion to set the terms of punishment without setting the conditions for the reward given as a result of the confession made by the accused. ${ }^{20}$

The obvious danger of unequal approach towards the sanctions imposed upon the offenders is another negative aspect connected with the sanction-

17 See Statistical Annuals of Crime, available on www.justice.cz

18 More details see Ščerba, F.: Alternativní tresty a opatření v nové právní úpravě. Praha: Leges 2011, p. 389-392.

19 Compare e.g. Šabata, K., Růžička, M.: Dohoda o vině a trestu de lege ferenda v České republice a možnosti využití slovenské právní úpravy. Státní zastupitelství 2009, no. 6, p. 10; Musil, J.: Dohody o vině a trestu jako forma konsenzuálního trestního řízení. Kriminalistika 2008, no. 1, p. 9.

20 For more details see Musil, J.: Dohody o vině a trestu jako forma konsenzuálního trestního ř́zení. Kriminalistika 2008, no. 1, p. 13-14. 
ing through the agreement upon the guilt and punishment made between the defense and the prosecution which is subsequently approved by the court. The negotiating skills of the accused and their defenders especially, workload of the individual state attorneys and judges as well as their willingness (influenced by different factors) to use different types of accelerated forms of criminal proceedings have all always played an important role when choosing the type and setting the terms of punishment even in the current application practice. However, the application of the institute of plea bargaining strengthens these elements even more.

However, certain substantive law acts, which can legitimately be taken into consideration in the sentencing process can be connected with the institute of plea bargaining. Speedy criminal proceedings and at thus accelerated sentencing process reached as a result of this special type of settling of the criminal case boost the efficiency of a punishment and enhances the perception of the legal protection against the crime provided by the state for the public. Thus a more modest sanction which is, however, imposed faster can have a bigger preventive effect both individually and generally compared to a stricter sanction applied after the standard criminal proceedings i.e. a sanction imposed after a longer period of time. ${ }^{21}$ The fact that the accused has accepted the punishment (declared by making the agreement upon the guilt and punishment) can also increase the probability of the fulfillment of the re-socialization aim of the punishment. However, it must be said that in a number of cases the defendant will probably want to make the agreement for tactical reasons, or even self-serving reasons, not because of the fact that he has frankly accepted the punishment as a reasonable and fair one. ${ }^{22}$ The stance of the accused towards the intended form of punishment (on which the possible acceptance of the sanction on the part of the accused is based) can also be collected through different standard means, e.g. using the position of a probation officer.

Thus, bearing in mind the principles of fair and reasonable sanctioning the settling of a case through the institute of plea bargaining seems to bring some drawbacks rather than advantages. These drawbacks must be perceived as the prize that has to be paid for the acceleration of the criminal proceedings, the prize being relatively high. If, however, the legislators intend to pay this prize and incorporate this element into the criminal law system, they should, at the same time, set at least basic framework and rules which would have to be taken into consideration when setting the sanctions within the process of plea bargaining.

The new Czech legal regulation has, in this respect, a large deficit in the area. Under the Czech legislation the courts are under the obligation to refuse to

21 Compare Král, V.: Dohoda o vině a trestu v návrhu novelizace trestního rádu. Právní rozhledy 2008, no. 20, p. II.

22 Compare e.g. Musil, J.: Dohody o vině a trestu jako forma konsenzuálního trestního řízení. Kriminalistika 2008, č. 1, s. 19. 
approve the motion for agreement upon the guilt and punishment submitted by the state attorney, in case this agreement is wrong or unreasonable as far as the type and terms of punishment, or precautionary measures are concerned (compare $\$ 314 \mathrm{r}$ clause 2 of the criminal procedure code). However, the legislator has not set any clues for such legal assessment, i.e. did not create any special rules covering the issues of sanctioning through agreement and punishment.

However, the Slovak criminal law regulation provides an example of such a rule. Under this legislation the performance of negotiation about the agreement upon the guilt and punishment itself can serve as a reason for an extraordinary lowering of a punishment. In such cases the imprisonment punishment can be lowered by one third under the lower limit of the prison term with the exception of most serious crimes fully listed where the punishment cannot be shorter than 20 years of imprisonment [compare according to $\$ 39$ clause 2 letter d) and clause 4 of the Slovak criminal law].

However, it must be pointed out that the imposing of a sanction of imprisonment under the lower limit of prison term in accordance with the rule described above is not a matter of course. This step is optional..$^{23}$ The form and the term of punishment must be agreed upon in accordance with general rules for sentencing so that the punishment agreed fulfilled its purpose. From this perspective it cannot be a punishment imposed under the lower limit of the prison term prescribed by law. Thus it is the prosecutor who should use the knowledge of the courts' practice when negotiating about the punishment. The prosecutor should also consider what punishment the court would probably impose in the specific case offering the accused a less severe punishment and in justifiable cases also a prison term lowered by one third; However, if the punishment agreed upon by the parties was not consistent with the principles of sentencing, the court would refuse to approve this proposal. ${ }^{24}$

\section{Conclusion}

The process of introducing of the institute of plea bargaining into the legal systems of Central European countries which is based on the negotiating about the punishment between the prosecution and the defendant could not have been done without certain collisions with the basic principles upon which the rules of criminal proceedings in these countries are based. Legislators must have been fully aware of this which can be seen especially when analyzing the Czech legal regulation under which it is not allowed to settle a case through the agreement upon the guilt and punishment in cases of prosecuting especially serious crimes,

23 Trylč, M.: Dohoda o vině a trestu ve slovenské právní úpravě: pohled obhajoby. In: Ščerba, F. a kol: Dohoda o vině a trestu a další prostředky racionalizace trestní justice. Prague: Leges 2012, p. 74.

24 Klátik, J.: Zrýchlenie a zhospodárnenie trestného konania. Banská Bystrica: Matej Bel University, 2010, p. 233, 235.

(C) Palacký University Olomouc, Czech Republic, 2013.

ISSN 1213-8770 (print), ISSN: 2464-6601 (online). 
i.e. intentional acts which carry the penalty of up to ten years imprisonment $(\$$ 14 clause 3 of criminal procedure code). This limitation can be regarded, in fact, as a taking into consideration of certain objections made in connection with this institute. It can also be regarded as a partial breakthrough or modification respectively of certain basic principles of criminal proceedings, namely the principle of material truth above all. In other words the legislation is explicitly based upon the notion that at least with the most serious crimes the agreement upon the guilt and punishment cannot be used as a substitute for the results of evidence presented and obtained during the trial, which means that with this category of offences the principles of criminal proceedings headed by the principle of material truth must be followed unexceptionally.

Thus it is logical that the Central European legal regulations of the institute of plea bargaining have been built in such a way that any possible intervention into the basic principles of the criminal proceedings would be minimized. This can be clearly seen especially in German legal regulation under which the German courts play a very important role in connection with this type of settling a case through the agreement upon the guilt and punishment. Thus the freedom of the two parties in criminal proceedings to make such an agreement is strictly limited.

However, the Czech and Slovak legal regulation of the negotiation about the agreement upon the guilt and punishment is much closer to the Anglo-Saxon model. However, even in these regulations efforts trying to limit any intervention into the basic principles of the criminal proceedings can obviously be seen. The most protected principle is the principle of material truth, at least as far as the letter of the law is concerned (the fact to what extent the authorities in criminal proceedings follow this law is another issue, as outlined above). Moreover, the Czech legislator has decided to support the fairness of the procedure by introducing the compulsory defense of the accused when negotiating about the agreement upon the guilt and punishment. At this stage no specific positive effects of the making of such agreement are mentioned and incorporated into the area of sanctioning (this, however, does not necessarily have to be seen as a positive aspect, as outlined above).

Thus the introduction of the institute of plea bargaining into the criminal law systems of Central European countries does not mean that the basic principles upon which this law is built have been denied and devastated at least in the form as it has been enshrined in the Czech, Slovak and German criminal law. This is also connected with the fact that this institute of settling criminal cases will probably not be used and applied to such extent as it has been applied in the countries where the legal systems are based on the Anglo-Saxon system of law; Thus this institute cannot be expected to solve the situation of excessive overload of the criminal justice system and the lengthy criminal proceedings resulting from this overload. Thus there is no other choice but hope that the legislator 
ICLR, 2013, Vol. 13, No. 1.

will finally incline to less popular, however, more effective way of solving this problem, i.e. the efforts to more intensive decriminalization and narrowing of the scope of criminal repression. 